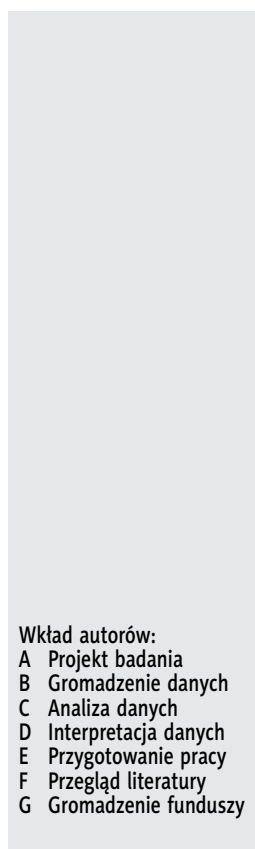

\title{
Przegląd kwestionariuszy stosowanych do oceny jakości życia u osób dorosłych głuchych (niedosłyszących) korzystających z implantu ślimakowego
}

\section{Review of questionnaires used to assess quality of life in deaf (hard of hearing) adults using a cochlear implant}

\author{
Joanna Rostkowska, ${ }^{1,2 \mathrm{EF}}$, Piotr H. Skarżyński ${ }^{1,2,3 F}$ \\ ${ }^{1}$ Instytut Fizjologii i Patologii Słuchu, Światowe Centrum Słuchu, Warszawa/Kajetany \\ ${ }^{2}$ Warszawski Uniwersytet Medyczny, II Wydział Lekarski, Zakład Niewydolności Serca \\ i Rehabilitacji Kardiologicznej, Warszawa \\ ${ }^{3}$ Instytut Narządów Zmysłów, Kajetany
}

Streszczenie

Celem artykułu jest przybliżenie zagadnienia jakości życia w naukach medycznych, przede wszystkim przegląd najczęściej stosowanych kwestionariuszy ogólnych i specyficznych przeznaczonych do badania jakości życia u osób dorosłych głuchych (niedosłyszących) korzystających z implantu ślimakowego (CI). Odzyskanie możliwości słyszenia ma pozytywny wpływ nie tylko na identyfikację dźwięków z otoczenia oraz rozumienie mowy, lecz także na zdrowie psychiczne oraz funkcjonowanie społeczne. Dlatego oprócz metod audiologicznego pomiaru percepcji słuchowej konieczne jest stosowanie kwestionariuszy, dzięki którym można ocenić jakość życia. Dopiero pomiar jakości życia związanej ze zdrowiem jest traktowany jako wskaźnik efektywności leczenia. Dodatkowo umożliwia określenie potrzeb pacjentów, a także ułatwia konstruowanie kompleksowych programów medyczno-terapeutycznych. Słowa kluczowe: implant ślimakowy • niedosłuch • głuchota • rehabilitacja • jakość życia

\section{Abstract}

The aim of this article is to bring forward the topic of quality of life in medical science and to present an overview of the most popular general and specific questionnaires for assessing the quality of life in deaf (hard of hearing) adult cochlear implant users. Restoration of the ability to hear has a positive effect not only on the identification of surrounding sounds and speech understanding, but also on the mental health and social functioning. This is why, besides the methods of audiological measurement of auditory perception, it is necessary to use questionnaires which allow assessing the quality of life. The health-related quality of life is considered to be an indicator of the efficacy of treatment. Moreover, it enables determining the needs of patients and facilitates developing comprehensive medical and therapeutic programs.

Key words: cochlear implant $\bullet$ hearing loss $\bullet$ deafness $\bullet$ rehabilitation $\bullet$ quality of life

Adres autora: Joanna Rostkowska, Światowe Centrum Słuchu, ul. Mokra 17, Kajetany, 05-830 Nadarzyn, e-mail: j.rostkowska@ifps.org.pl 
Wykaz skrótów zgodnie z kolejnością alfabetyczną / List of abbreviations in the alphabetical order

\begin{tabular}{ll}
\hline \multicolumn{1}{c}{ Skrót } & \multicolumn{1}{c}{ Rozwinięcie } \\
\hline AQoL & Assessment of Quality of Life \\
\hline CI & Cochlear implant - Implant ślimakowy \\
\hline GBI & Glasgow Benefit Inventory \\
\hline GHSI & Glasgow Health Status Inventory \\
\hline HHIA & Hearing Handicap Inventory for Adults \\
\hline HUI 2 & Health Utilities Index Mark II \\
\hline
\end{tabular}

\begin{tabular}{ll}
\hline \multicolumn{1}{c}{ Skrót } & \multicolumn{1}{c}{ Rozwinięcie } \\
\hline HUI 3 & Health Utilities Index Mark III \\
\hline HPS & Hearing Participation Scale \\
\hline IRQF & Index Relative Questionnaire Form \\
\hline NCIQ & Nijmegen Cochlear Implant Questionnaire \\
\hline PQLF & Patients Quality Life Form \\
\hline SF-36 & Short Form Health Survey \\
\hline
\end{tabular}

\section{Wstęp}

Zastosowanie implantów ślimakowych w wypadku osób dorosłych ze znacznym lub głębokim niedosłuchem, a także z częściową głuchotą stanowi skuteczną formę rehabilitacji medycznej [1-3].

Większość prac naukowych poświęconych zagadnieniu wszczepiania implantów ślimakowych u osób dorosłych koncentruje się na badaniach określających możliwości percepcji słuchowej dźwięków otoczenia oraz dźwięków mowy przed wszczepieniem implantu ślimakowego i po jego zastosowaniu. Na ogół wykazują one istotną różnicę statystyczną w tych zakresach, dowodząc, iż korzystanie z implantu ślimakowego umożliwia słuchową identyfikację dźwięków z otoczenia oraz percepcję słuchową mowy w ciszy i w hałasie [4]. Ograniczanie się tylko do stosowania metod pomiaru (testy audiologiczne) charakterystycznych dla podejścia biomedycznego nie uwidacznia pełnego spektrum zysków osiąganych po zastosowaniu metody leczenia za pomocą implantu ślimakowego. Praktyka terapeutyczna wskazuje, że odzyskanie możliwości słyszenia wpływa pozytywnie również na zdrowie psychiczne oraz funkcjonowanie społeczne, a w niektórych wypadkach nawet na zdrowie fizyczne. Podsumowując, stosowanie metod audiologicznego pomiaru percepcji słuchowej jest konieczne, ale potrzebne są także badania oceniające subiektywny wpływ zastosowania implantu ślimakowego na psychologiczne, społeczne oraz fizyczne aspekty życia osób korzystających z CI. Dopiero taki kompleksowy sposób traktowania pacjenta, właściwy dla holistycznego modelu opieki medycznej [5], daje całościowy obraz funkcjonowania człowieka wyrażany jako jakość życia. Ocena jakości życia jest niezwykle cenna, ponieważ ma charakter wielowymiarowy i jest wyrazem subiektywnych odczuć. Dodatkowo cechuje się zmiennością związaną z upływem czasu, co daje możliwość ponownej oceny, porównania wyników i zastosowania odpowiednich interwencji.

Celem niniejszej pracy jest przegląd kwestionariuszy ogólnych i specyficznych służących do badania jakości życia różnych grup osób dorosłych, które zostały zaopatrzone $\mathrm{w}$ implant ślimakowy. Piśmiennictwo na ten temat $\mathrm{z}$ reguły dotyczy dorosłych osób, które ogłuchły po opanowaniu systemu językowego. W opracowaniu znalazły się także publikacje dotyczące badania jakości życia u osób, które ogłuchły przed opanowaniem systemu językowego, osób z głuchotą jednostronną oraz osób z częściową głuchotą.

\section{Badanie jakości życia związanej ze zdrowiem [HRQoL]}

WHO definiuje pojęcie jakości życia jako „indywidualny sposób postrzegania przez jednostkę jej pozycji życiowej w kontekście kulturowym i systemu wartości, w którym żyje, oraz w odniesieniu do zadań, oczekiwań i standardów wyznaczonych uwarunkowaniami środowiskowymi” [6].

Miarą sukcesu współczesnej medycyny jest poprawa jakości życia związanej ze zdrowiem. Dlatego pomiar jakości życia jest istotnym i stosowanym równolegle $\mathrm{z}$ oceną medyczną wyznacznikiem skuteczności proponowanego leczenia. Ponadto korzystając $\mathrm{z}$ narzędzi diagnostycznych przeznaczonych do badania jakości życia związanej ze zdrowiem (HRQoL), można ocenić wpływ choroby i leczenia na funkcjonowanie człowieka nie tylko w zakresie fizycznym, lecz także psychologicznym i społecznym. Ocenia się ją, wykorzystując przeznaczone do tego, wystandaryzowane narzędzia badawcze o charakterze ogólnym lub specyficznym [7]. Jednak kwestionariusze ogólne mogą okazać się mało wrażliwe na zmiany związane z określona chorobą czy też z przebiegiem jej leczenia. Dlatego kwestionariusze specyficzne, przeznaczone dla osób $\mathrm{z}$ daną jednostką chorobową, są konstruowane w taki sposób, by umożliwić ocenę tych aspektów zdrowia, na które ta choroba ma wpływ.

Do oceny jakości życia osób dorosłych leczonych przy użyciu implantów ślimakowych korzysta się przede wszystkim z kwestionariuszy ogólnych, takich jak: Short Form Health Survey (SF-36), Glasgow Health Status Inventory (GHSI), Glasgow Benefit Inventory (GBI), Health Utilities Index Mark II (HUI 2), Health Utilities Index Mark III (HUI 3), Assessment of Quality of Life (AQoL), Hearing Participation Scale (HPS), Hearing Handicap Inventory for Adults (HHIA). Natomiast kwestionariusze przeznaczone dla osób, które użytkują implanty ślimakowe, to: $\mathrm{Pa}$ tients Quality Life Form (PQLF), Index Relative Questionnaire Form (IRQF) oraz najczęściej stosowany Nijmegen Cochlear Implant Questionnaire (NCIQ).

\section{Zastosowanie kwestionariuszy ogólnych do mierzenia jakości życia zwiąanej ze zdrowiem u dorosłych osób korzystających $z$ implantu ślimakowego}

\section{Short Form Health Survey (SF-36)}

Kwestionariusz SF-36 ma bardzo szerokie zastosowanie w różnych jednostkach chorobowych [8-14]. Zawiera 36 pozycji, które zostały podzielone na 8 kategorii: 
1. Sprawność fizyczna (np. Czy Twoje zdrowie ogranicza Twoje możliwości wykonywania codziennych czynności?).

2. Ograniczenie aktywności z powodu zdrowia fizycznego (np. Czy w ostatnim miesiącu miałeś problemy z praca lub codzienna aktywnością, które wynikały ze stanu zdrowia).

3. Ograniczenie aktywności z powodu problemów emocjonalnych (np. Czy w ciagu ostatniego miesiaca miateś problemy $z$ wykonywana praca lub codziennymi aktywnościami wynikające z problemów emocjonalnych?).

4. Dolegliwości bólowe (np. Jak często odczuwałeś ból $w$ ciagu ostatniego miesiąca?).

5. Ogólna percepcja zdrowia (np. Generalnie możesz powiedzieć, że stan Twojego zdrowia jest: doskonały, dobry, niezadowalający, bardzo dobry, zadowalajacy).

6. Funkcjonowanie społeczne (np. Czy w ciagu ostatniego miesiąca Twoje problemy zdrowotne lub emocjonalne miały wplyw na zwyczajne czynności, kontakty $z$ rodzina, przyjaciółmi, sąsiadami lub innymi grupami?).

7. Witalność (np. Byłeś pełen animuszu?).

8. Zdrowie psychiczne (np. Byłeś załamany i smutny?).

Kwestionariusz SF-36 zastosowało wielu autorów badających jakość życia osób dorosłych korzystających z implantu ślimakowego [15-20]. Otrzymane wyniki z reguły prowadziły do wnioskowania, że nie jest to wystarczająco czułe narzędzie do oceny jakości życia związanej ze zdrowiem w tej grupie badanej [17-20]. Hirschfelder i wsp. użyli SF-36 do zbadania 56 osób postlingwalnie ogłuchłych zaopatrzonych w implant ślimakowy i nie odnotowali statystycznie istotnych różnic świadczących o zmianie jakości życia po zastosowaniu urządzenia [17].

Kwestionariusz SF-36 jest zaadaptowany kulturowo do języka polskiego. Wypełnienie kwestionariusza zajmuje około 10 minut.

\section{Health Utilities Index Mark II (HUI 2) oraz Health Utilities Index Mark III (HUI 3)}

HUI 2 pozwala na ocenę jakości życia zależnej od stanu zdrowia w obszarach:

1. Odczuwanie (zmysły) (np. Able to see, hear, and speak normally for age $)^{1}$.

2. Poruszanie się (np. Walks, bends, lifts, jumps, or runs with some limitations but does not require help).

3. Emocje (np. Generally happy and free from worry).

4. Funkcje poznawcze (np. Learns and remember very slowly and usually requires special educational assistance).

5. Czynności codzienne (samoopieka) (np. eats, bathes, dresses and uses the toilet normally for age).

6. Ból (np. Free of pain and discomfort).

Wersja zmodyfikowana - HUI 3 umożliwia ocenę jakości życia zależnej od zdrowia w obszarach:

1. Wzrok (np. Able to read ordinary newsprint with or without glasses but unable to recognize a friend on the other side of the street, even with glasses $)^{2}$.

2. Słuch (np. Able to hear what is said in a conversation with one other person in a quiet room without a hearing aid, but requires hearing aid to hear what is said in a group conversation with at least three other people).

3. Mowa (np. Able to be understood partially when speaking with strangers but able to be understood completely when speaking with people who know me well).

4. Poruszanie się (np. Able to walk around the neighborhood with difficulty, buy does not require walking equipment or the help of another person).

5. Sprawność (np. Fool use of two hands and ten fingers).

6. Emocje (np. Somewhat happy).

7. Funkcje poznawcze (np. Able to remember most things, think clearly and solve day to day problems).

8. Ból (np. Free of pain and discomfort) [21].

Krabbe i wsp. zastosowali Indeks HUI-2 w grupie 45 osób postlingwalnie ogłuchłych i korzystających $\mathrm{z}$ implantu ślimakowego i stwierdzili znaczącą statystycznie różnicę świadczącą o wzroście jakości życia [16]. Damen i wsp. zbadali osoby, które utraciły słuch przed opanowaniem systemu językowego (prelingwalnie), przed wszczepieniem i 5 miesięcy po wszczepieniu implantu ślimakowego i odnotowali istotną statystycznie poprawę jakości życia w obszarze odczuwania (zmysły), co wpłynęło na istotny statystycznie wzrost ogólnej jakości życia związanej ze zdrowiem. Natomiast do badania 22 osób, które utraciły słuch po opanowaniu systemu językowego (postlingwalnie), użyli kwestionariusza HUI-3 i uzyskali znaczący statystycznie wzrost jakości życia w obszarach słuchania mowy oraz emocji, co spowodowało istotny statystycznie wzrost ogólnej jakości życia [18]. Podobne wyniki opisał Francis i wsp. (2002), zaznaczył jednak, że osoby, które utraciły słuch prelingwalnie, osiągnęły gorsze wyniki niż ci, którzy utracili słuch postlingwalnie [22]. Arndt i wsp. (2011) wykorzystali indeks HUI-3 do oceny jakości życia osób korzystających z implantu ślimakowego z powodu jednostronnej głuchoty. Otrzymane wyniki wskazały na istotną statystycznie poprawę ogólnej jakości życia po zastosowaniu implantu ślimakowego w stosunku do wyników badania przeprowadzonego przed zaimplantowaniem oraz w stosunku do wyników osób z jednostronną głuchotą korzystających z aparatu słuchowego [23].

Kwestionariusze nie są zaadaptowane do języka polskiego. Wypełnienie kwestionariusza zajmuje 10 minut.

\section{Glasgow Health Status Inventory (GHSI)}

Kwestionariusz GHSI umożliwia ocenę wpływu problemów zdrowotnych na jakość życia. Składa się z 18 pozycji podzielonych na trzy kategorie:

1. Ogólną (12 pytań) (np. How much does your health problem affect your overall life? $)^{3}$.

2. Społeczną (3 pytania) (np. How often does any difficulty with your health problem affect how you deal with company?).

3. Fizyczną (3 pytania) (np. How often do you have to take medicine for any reason?).

Możliwa jest ocena całkowitej jakości życia.

\footnotetext{
1. Przykładowe pozycje kwestionariusza są podane w języku angielskim, gdyż nie ma oficjalnej polskiej adaptacji tego narzędzia.

2. Przykładowe pozycje kwestionariusza są podane w języku angielskim, gdyż nie ma oficjalnej polskiej adaptacji tego narzędzia.

3. Przykładowe pozycje kwestionariusza są podane w języku angielskim, gdyż nie ma oficjalnej polskiej adaptacji tego narzędzia.
} 
Orabi i wsp. (2006) użyli GHSI do oceny jakości życia 38 osób postlingwalnie ogłuchłych, którym wszczepiono implant ślimakowy po 65 roku życia. Opisali istotną statystycznie poprawę w ocenie całkowitej i jakości życia po zastosowaniu urządzenia [24]. Barton i wsp. (2004) porównali wyniki uzyskane po zastosowaniu GHSI przez osoby korzystające $z$ implantu ślimakowego do wyników uzyskanych przez osoby korzystające z 2 implantów ślimakowych. Autorzy opisali istotną statystycznie poprawę jakości życia wśród osób korzystających z 2 implantów ślimakowych [25].

Do wypełnienia kwestionariusza potrzeba około $10 \mathrm{mi}-$ nut. Kwestionariusz nie został zaadaptowany do języka polskiego

\section{Assessment of Quality of Life (AQoL)}

Kwestionariusze AQoL są przeznaczone do badania jakości życia zależnej od zdrowia.

Powstało kilka wersji kwestionariusza AQoL, między innymi: AQoL-8D, AQoL-7D, AQoL-6D, AQoL-4D.

Hawthorne i wsp. (2004) użyli AQoL do zbadania 34 dorosłych osób ogłuchłych po opanowaniu systemu językowego, korzystających z implantu ślimakowego. Badanie wykonano trzykrotnie: przed wszczepieniem implantu ślimakowego oraz 3 i 6 miesięcy od podłączenia procesora mowy. Badacze wykazali, że jakość życia wzrosła po 3 miesiącach od rozpoczęcia korzystania $z$ urządzenia, a po 6 miesiącach nastąpił jej dalszy wzrost [26].

Kwestionariusz AQoL-8D został zaadaptowany do języka polskiego przez badaczy z Instytutu Fizjologii i Patologii Słuchu. AQoL-8D uwzględnia model Międzynarodowej Klasyfikacji Funkcjonowania, Niepełnosprawności i Zdrowia (ICF) w aspekcie pomiarów jakości życia związanej ze zdrowiem (HRQoL) [27].

AQoL-8D składa się z 35 pozycji obejmujących wymiary: 1. Niezależność (np. Biorąc pod uwage twoje możliwości poruszania się, również przy użyciu sprzętów wspomagajacych, np. wózek inwalidzki, balkonik, laska: a. Poruszam się zupetnie swobodnie, $b$. Nie mam problemów $z$ poruszaniem się c. Mam pewne problemy z poruszaniem się (np. wchodzenie pod górę) d. Mam problemy $z$ poruszaniem się. Mogę pokonać jedynie krótki dystans e. Mam duże problemy z poruszaniem się. Potrzebuje pomocy innej osoby $f$. Jestem przykuty do łóżka).

2. Sprawność zmysłu wzroku (np. Biorac pod uwage stan twojego wzroku ( $w$ okularach lub w soczewkach kontaktowych), jeśli ich potrzebujesz: a. Mam doskonały wzrok, b. Widzę normalnie, c. Mam niewielkie problemy ze skupieniem wzroku na przedmiotach lub nie widzę ich wyraźnie, np. mały druk, druk w gazecie lub widzenie obiektów znajdujących się $w$ oddali, d. Mam duże problemy $z$ widzeniem przedmiotów. Widzę niewyraźnie. Widzę tylko tyle, aby sobie radzić, e. Widze tylko zarysy przedmiotów. Potrzebuję pomocy /przewodnika przy poruszaniu się, f. Jestem niewidomy).
3. Sprawność zmysłu słuchu (np. Biorac pod uwage stan twojego stuchu ( $w$ urzadzeniach wspomagających styszenie, jeśli ich potrzebujesz): a. Mam doskonaty stuch, b. Styszę normalnie, c. Mam niewielkie problemy ze styszeniem lub nie słyszę wyraźnie. Mam kłopoty ze słyszeniem osób mówiących cicho lub kiedy w otoczeniu panuje hałas, d. Mam problemy z wyraźnym słyszeniem. Często nie rozumiem tego, co zostało powiedziane. Zwykle nie biorę udziału $w$ rozmowach, ponieważ nie słysze tego, co zostało powiedziane, e. Styszę naprawdę bardzo niewiele. Nie mogę w petni zrozumieć głośnych wypowiedzi skierowanych bezpośrednio do mnie, f. Jestem kompletnie gtuchy).

4. Ból (np. Biorąc pod uwage to, jak często odczuwasz silny ból. Odczuwam go: a. bardzo rzadko, b. rzadziej niż raz $w$ tygodniu, c. trzy do czterech razy $w$ tygodniu, $d$. przez większość czasu).

5. Zdrowie psychiczne (np. Jak często czujesz złość? a. nigdy, b. prawie nigdy, c. czasami, d. często, e. cały czas).

6. Szczęście (np. Jak często czujesz się szczęśliwy? a. cały czas, b. często, c. czasami, d. prawie nigdy, e. nigdy).

7. Poczucie własnej wartości (np. W jakim stopniu jesteś pewny siebie? a. całkowicie pewny siebie, $b$. $w$ dużym stopniu, c. $w$ średnim stopniu, d. $w$ niewielkim stopniu, e. wcale).

8. Umiejętność radzenia sobie z codziennymi obowiązkami (np. Biorac pod uwage mycie się, toaletę, ubieranie się, jedzenie lub dbanie o wyglad: a. Czynności te sa dla mnie bardzo łatwe, $b$. Nie mam dużych trudności $z$ wykonywaniem tych czynności, c. Niektóre $z$ tych czynności sa dla mnie trudne, ale udaje mi się je wykonywać samodzielnie, $d$. Wiele tych czynności jest dla mnie trudnych i potrzebuje pomocy przy ich wykonywaniu, e. Nie moge wykonywać tych czynności samodzielnie).

9. Relacje społeczne (np. Biorąc pod uwagę twój stan zdrowia i twoje relacje rodzinne: a. Moja rola $w$ rodzinie nie zależy od mojego stanu zdrowia, b. Sa pewne role $w$ rodzinie, nie moge pełnić $w$ rodzinie żadnej roli).

Do wypełnienia kwestionariusza potrzeba około 10 minut.

\section{Zastosowanie kwestionariuszy specyficznych do mierzenia jakości życia związanej ze zdrowiem - słuchem u osób dorosłych korzystających $\mathrm{z}$ implantu ślimakowego}

\section{Glasgow Benefit Inventory (GBI)}

Kwestionariusz (GBI) służy do subiektywnej oceny zmiany w stanie zdrowia w następstwie interwencji otorynolaryngologicznej i oceny, czy interwencja okazała się dla chorego korzystna czy nie. Kwestionariusz zawiera 18 pozycji, określających samoocenę wpływu zastosowanego leczenia na zmianę $\mathrm{w}$ funkcjonowaniu chorego w zakresach:

1. Ogólnym (12 pytań) (np. Have the results of the operation/intervention ${ }^{*}$, made your overall life better or worse $)^{4}$.

2. Społecznym (3 pytania) (np. Since your operation/intervention ${ }^{*}$, have you been able to participate in more or fewer social activities?).

3. Fizycznym (3 pytania) (np. Since you had the operation/ intervention*, do you catch colds or infections more or less often?) [28]. 
Ocena jest dokonywana po leczeniu, w okresie, gdy pozytywne efekty powinny być odczuwane przez chorego. Wynik kwestionariusza umożliwia porównanie odczuwanych przez chorych efektów różnych sposobów leczenia danego schorzenia oraz efektów leczenia w różnych schorzeniach otorynolaryngologicznych [28-32].

Vermaire i wsp. (2005) użyli kwestionariusza GBI do oceny jakości życia 89 osób ogłuchłych postlingwalnie, korzystających z implantu ślimakowego. Otrzymane wyniki świadczyły o istotnej statystycznie poprawie jakości życia w zakresie ogólnym i społecznym [33].

Do wypełnienia kwestionariusza potrzeba około $10 \mathrm{mi}$ nut. Kwestionariusz GBI nie jest zaadaptowany do języka polskiego.

\section{Hearing Participation Scale (HPS)}

Kwestionariusz HPS jest skróconą formą Glasgow Health Status Inventory (GHSI). Składa się z 11 stwierdzeń podzielonych między 3 kategorie:

1. Poczucie własnej wartości (np. Since you get your cochlear implant does your hearing problem affected the way you feel about yourself).

2. Relacje społeczne (np. Since you get your cochlear implant how often do you get together with friends).

3. Słuchanie (np. Since you get your cochlear implant how often are you embarrassed with the group of people).

Wyniki osiągnięte przez przebadane tym kwestionariuszem 34 dorosłe osoby ogłuchłe postlingwalnie i korzystające z implantu ślimakowego wskazują na istotną statystycznie poprawę ogólnej jakości życia po 3 i 6 miesiącach od podłączenia procesora mowy [26]. Na wypełnienie kwestionariusza potrzeba 10 minut. Kwestionariusz nie jest zaadaptowany do języka polskiego.

\section{Hearing Handicap Inventory for Adults (HHIA)}

Kwestionariusz HHIA umożliwia ocenę wpływu problemów związanych ze słuchem na sfery:

1. Emocjonalną (np. Does a hearing problem make you irritable?) ${ }^{5}$.

2. Socjalną (np. Does a hearing problem cause you difficulty when visiting friends, relatives, or neighbors?).

Narzędzie zawiera 25 pozycji $[34,35]$.

Vermaier i wsp. (2005) użyli go do zbadania 130 dorosłych osób ogłuchłych postlingwalnie przed operacją i po operacji wszczepienia implantu ślimakowego. Uzyskali wyniki wskazujące na istotną statystycznie poprawę w zakresie funkcjonowania emocjonalnego i poprawę ogólnej jakości życia po zastosowaniu implantu ślimakowego [33].

Do wypełnienia kwestionariusza potrzeba 10 minut. Kwestionariusz nie jest adaptowany do języka polskiego.

\section{Zastosowanie kwestionariuszy specyficznych przeznaczonych do mierzenia jakości życia u osób dorosłych korzystających $\mathrm{z}$ implantu ślimakowego}

Skonstruowano kilka kwestionariuszy służących do badania jakości życia osób dorosłych korzystających z implantu ślimakowego: Patients Quality Life Form (PQLF) [36], Index Relative Questionnaire Form (IRQF) [37] oraz Nijmegen Cochlear Implant Questionnaire (NICQ) [15]. Dwa pierwsze kwestionariusze powstały w latach 80 . ubiegłego wieku, były dostosowane do ówczesnych możliwości medycznych i oczekiwań pooperacyjnych. Obecnie nie są stosowane.

\section{Nijmegen Cochlear Implant Questionnaire (NCIQ)}

Za pomocą NCIQ można ocenić wpływ korzystania z implantu ślimakowego na jakość życia w obrębie trzech sfer:

1. Fizycznej,

2. Psychologicznej,

3. Społecznej.

Każda ze sfer (domen) zawiera charakterystyczne subdomeny.

Ad 1. Na sferę fizyczną składają się subdomeny oceniające możliwości percepcji dźwięku (podstawowa - dźwięki otoczenia, zaawansowana - rozumienie mowy w ciszy i w hałasie, rozmowa telefoniczna, rozpoznawanie głosu męskiego i damskiego, rozpoznawanie rytmu, melodii, radość ze słuchania muzyki) oraz sposób mówienia (kontrola natężenia, wyrażanie emocji głosem).

Ad 2. Sfera psychologiczna jest zbudowana $\mathrm{z}$ jednej subdomeny określającej poczucie własnej wartości (łatwość konwersacji, akceptacje niedosłuchu, unikanie, zawieranie nowych znajomości).

Ad 3. Sferę społeczną stanowią dwie subdomeny dotyczące aktywności (aktywność związana z pracą, nauką, hobby, spędzaniem wolnego czasu) i relacji społecznych (komunikowanie się $\mathrm{z}$ ludźmi).

Zadaniem pacjenta wypełniającego kwestionariusz jest ustosunkowanie się do 60 pozycji za pomocą 5-stopniowej skali Likerta.

Kwestionariusz nie jest zaadaptowany do języka polskiego. Do jego wypełnienia potrzeba 10 minut.

Autorzy kwestionariusza NCIQ - Hinderink, Krabbe i wsp. (2000) zbadali grupę 45 dorosłych pacjentów przed wszczepieniem i po wszczepieniu implantu ślimakowego i otrzymane wyniki porównali z wynikami 46 pacjentów oczekujących na operację wszczepienia implantu ślimakowego. Wykazali istotną statystycznie poprawę we wszystkich 6 subdomenach $\mathrm{w}$ badaniu przeprowadzonym po zastosowaniu implantu ślimakowego. Szczególną różnicę zauważyli w subdomenach: podstawowej i zaawansowanej percepcji dźwięków. Odnotowali także istotną statystycznie

5. Przykładowe pozycje kwestionariusza są podane w języku angielskim, gdyż nie ma oficjalnej polskiej adaptacji tego narzędzia. 
poprawę wyników grupy badanej we wszystkich subdomenach w stosunku do wyników grupy kontrolnej. Podkreślili, iż nie występuje zależność między wynikami NCIQ a czasem trwania niedosłuchu i wiekiem w momencie wszczepienia implantu ślimakowego. Autorzy nie stwierdzili korelacji między wynikami testów oceniających percepcję słuchową a poszczególnymi subdomenami NCIQ [15]. Po 6 latach Damen i wsp. (2007) ponownie zastosowali w grupie badanej kwestionariusz NCIQ i potwierdzili utrzymującą się istotnie statystyczną poprawę w 5 subdomenach, z wyjątkiem subdomeny dotyczącej relacji społecznych. Tym razem otrzymano korelację między średnim wynikiem NCIQ a testami oceniającymi percepcję słuchową (testy fonemowe i sylabowe) [18].

Także Hirschfelder i wsp. (2008) zastosowali kwestionariusz NCIQ w grupie dorosłych pacjentów (56 osób) z niedosłuchem przed operacją i po operacji wszczepienia implantu ślimakowego i podobnie jak Hinderink i wsp. (2000) odnotowali istotną statystycznie poprawę we wszystkich subdomenach, a największą statystyczną różnicę wykazali w subdomenach badających percepcję dźwięku [15]. Podobnie jak Damen i wsp. (2007) wykazali oni korelację między wynikami kwestionariusza NCIQ a testami badającymi możliwości percepcji słuchowej mowy $[17,18]$.

Sanchez-Cuadrado i wsp. (2015) zastosowali kwestionariusz NCIQ w wersji retrospektywnej w grupie 76 pacjentów, którym wszczepiono implant ślimakowy. Otrzymane wyniki, mimo zastosowania wersji retrospektywnej, nie różniły się od wyników raportowanych przez innych badaczy. Odnotowano statystycznie istotny wzrost jakości życia związanej ze zdrowiem, który dotyczył wszystkich subdomen, a szczególnie subdomen oceniających podstawowe możliwości percepcji dźwięków oraz sposób (technikę) mówienia. Autorzy określili NCIQ jako wyjątkowo wartościowe narzędzie umożliwiające określenie subiektywnych korzyści $\mathrm{z}$ wszczepienia implantu ślimakowego i stwierdzili, że może być stosowane w hiszpańskiej wersji językowej [38].

Liu i wsp. (2008) zbadali 32 osoby postlingwalnie ogłuchłe korzystające z implantu ślimakowego dłużej niż 6 miesięcy i otrzymali istotny statystycznie wzrost świadczący o poprawie jakości życia w obszarach dotyczących percepcji dźwięków, relacji społecznych i poczucia własnej wartości. Autorzy orzekli, że NCIQ jest narzędziem, które może być wykorzystywane do badania jakości życia po zastosowaniu implantu ślimakowego w populacji chińskiej [39].

Cohen i wsp. (2004) porównali wyniki otrzymane w NCIQ w grupie 24 pacjentów korzystających z implantu ślimakowego $z$ wynikami uzyskanymi po zbadaniu 27 dorosłych osób korzystających z aparatów słuchowych. Dane zebrano retrospektywnie. Autorzy dowiedli, że kwestionariusz może być stosowany u pacjentów używających aparatów słuchowych. Wykazali korelację między wynikami NCIQ a wynikami testów oceniających słuchową percepcję mowy [40].

Damen i wsp. (2006) wykorzystali kwestionariusz NCIQ do oszacowania jakości życia związanej z zastosowaniem implantu ślimakowego w 22-osobowej grupie pacjentów z zespołem Ushera (typ I) i wykazali znaczącą statystycznie poprawę w subdomenach oceniających możliwości percepcji dźwięków po wszczepieniu urządzenia [41].

Klop i wsp. (2007) opisali wyniki NCIQ 8 pacjentów z głuchotą prelingwalną i wykazali, że po 4 miesiącach od operacji wszczepienia implantu ślimakowego pacjenci uzyskali znaczący wpływ na możliwość percepcji dźwięków oraz relacje społeczne. Wyniki badania wykonanego 12 i 30 miesięcy po wszczepieniu implantu ślimakowego nie uległy zmianie [42].

Mistry i wsp. (2014) zastosowali kwestionariusz NCIQ nie tylko w stosunku do osób implantowanych, lecz także do ich partnerów. Wyniki pokazały, że pacjenci i ich partnerzy w bardzo podobny sposób oceniają wpływ implantu ślimakowego na jakość życia. Autorzy zauważyli, iż osoby użytkujące implant ślimakowy lepiej niż ich partnerzy oceniali swoje możliwości w zakresie podstawowej percepcji dźwięków. Badacze tłumaczyli to tym, że osoby zaimplantowane mogą nie być świadome, których dźwięków nie słyszą [43].

Problem zależności między jakością życia a słuchową percepcją mowy u pacjentów korzystających $\mathrm{z}$ implantu ślimakowego zbadała Capretta i wsp. (2016). Według nich wyniki testów przeznaczonych do oceny percepcji słuchowej mowy w ciszy nie korelują $\mathrm{z}$ wynikami kwestionariuszy do badania jakości życia zależnej od zdrowia osób korzystających z implantów ślimakowych. Dowodzą także, że wiek pacjenta, czas trwania niedosłuchu, czas korzystania z implantu ślimakowego, status ekonomiczny, zasób słownikowy, możliwości poznawcze nie są predykatorami wyników osiąganych w kwestionariuszach przeznaczonych do badania jakości życia zależnej od zdrowia [44].

Badacze nie są zgodni co do zależności między wynikami uzyskiwanymi po zastosowaniu narzędzi służących do badania jakości życia związanej ze zdrowiem a wynikami audiologicznych testów percepcji słuchowej mowy, czasem trwania niedosłuchu, czasem korzystania z implantu ślimakowego $[17,40]$.

\section{Wnioski}

Pojęcie jakości życia służy do całościowej oceny stanu pacjenta, ułatwia zaplanowanie i zorganizowanie opieki medycznej oraz świadczy o całościowym podejściu do procesu leczenia. Badania nad jakością życia osób dorosłych korzystających z implantu ślimakowego są w Polsce wciąż nowością, chociażby z powodu braku narzędzia badawczego adaptowanego do języka polskiego.

Najodpowiedniejszymi narzędziami badającymi wpływ zastosowania implantu ślimakowego na jakość życia są kwestionariusze specyficzne, przeznaczone dla tej grupy osób, takie jak NCIQ.

Kwestionariusze ogólne typu Short Form Health Survey (SF-36), Health Utilities Index Mark II (HUI 2), Health Utilities Index Mark III (HUI 3) nie są wystarczająco czułe i w tym wypadku nie powinny być stosowane jako wyłączne narzędzia do oceny jakości życia u osób korzystających z implantu ślimakowego. 
Ciekawym zagadnieniem jest oszacowanie zależności między wynikami testów badających percepcję słuchową a oceną jakości życia osób korzystających z implantu ślimakowego, ponieważ niektórzy badacze zauważają wzrost jakości życia wraz ze wzrostem umiejętności percepcji słuchowej, inni nie raportują takiej zależności.

Najprawdopodobniej istnieją jeszcze inne czynniki wpływające na jakość życia w tej grupie pacjentów, a jednym $\mathrm{z}$ nich może być depresja. Inne czynniki mogą być związane $\mathrm{z}$ funkcjonowaniem społecznym.

\section{Podsumowanie}

Obecnie pomiar jakości życia związanej ze zdrowiem jest traktowany jako wskaźnik efektywności leczenia. Pozwala na oszacowanie potrzeb pacjentów, a także ułatwia konstruowanie kompleksowych programów medyczno-terapeutycznych przeznaczonych dla wybranych grup chorych. Umożliwia monitorowanie wyników leczenia, dobór odpowiednich metod leczniczych, wprowadzenie ewentualnych zmian kryteriów diagnostycznych, zastosowanie odpowiednich interwencji z innych obszarów (np. interwencje psychologiczne), zoptymalizowania kosztów leczenia, podniesienie poziomu jakości opieki medycznej.

Przeprowadzenie badania jakości życia związanej ze zdrowiem niewątpliwie ułatwia komunikację i współpracę lekarz - pacjent [45]. Lekarz może lepiej zrozumieć problemy pacjenta i zaproponować odpowiednie działanie medyczne lub rehabilitacyjne. Pacjent otrzyma nie tylko leczenie, lecz także zainteresowanie i wsparcie.

Wartością dla pacjenta jest już samo wypełnienie kwestionariusza na temat jakości życia, ponieważ może to sprzyjać autorefleksji nad swoimi oczekiwaniami, osiągniętymi umiejętnościami, mocnymi stronami i obszarami do dalszej pracy rehabilitacyjnej lub psychologicznej.

Można założyć, że poziom jakości życia uzyskanej dzięki zastosowaniu leczenia jest miarą satysfakcji z leczenia.

\section{Piśmiennictwo:}

1. Skarżyński H, Szuchnik J, Mueller-Malesińska M. Implanty ślimakowe - rehabilitacja. Warszawa: Stowarzyszenie Przyjaciół Osób Niesłyszących i Niedosłyszących; 2004.

2. Cochlear implants for children and adults with severe to profound deafness | Guidance and guidelines | NICE, $h t t p s: / / w w w$. nice.org.uk/guidance/ta166

3. Lorens A. Model rehabilitacji audiologicznej po wszczepieniu implantu ślimakowego opracowany na podstawie Międzynarodowej Klasyfikacji Funkcjonowania, Niepełnosprawności i Zdrowia (ICF). Now Audiofonol, 2015; 3(5): 77-90.

4. Sladen DP, Zappler A. Older and younger adult cochlear implant users: Speech recognition in quiet and noise, quality of life, and music perception. Am J Audiol, 2015; 24(1): 31-39.

5. Gaweł A, Kowalski M. Zdrowie. Wartość. Edukacja. Kraków: Oficyna Wydawnicza „Impuls”; 2006.

6. WHOQOL Group. The World Health Organisation quality of life assessment (WHOQOL): Position paper from the World Health Organisation. Soc. Sci. Med., 1995; 41: 1403-409.

7. Guyatt GH, Feeny DH, Patrick DL. Measuring health-related quality of life. Ann Intern Med, 1993; 118(8): 622-29.

8. Kielnar R, Domka-Jopek E. Znaczenie oceny jakości życia przed i po 3-miesięcznej ambulatoryjnej kardiologicznej rehabilitacji grupowej pacjentów z choroba wieńcową. Przegląd Med Uniw Rzesz, 2005; 4: 351-66.

9. Felce D, Perry J. Quality of life: Its definition and measurement. Res Dev Disabil, 1995; 16(1): 51-74.

10. Łazowski J. Opieka farmaceutyczna. W: Opieka farmaceutyczna w praktyce aptecznej. Warszawa: Oficyna Wydawnicza Akademii Medycznej; 2005.

11. Luscombe FA. Health-related quality of life measurement in type 2 diabetes. Value Health J Int Soc Pharmacoeconomics Outcomes Res, 2000; 3(Suppl. 1): 15-28.

12. Ware JE, Sherbourne CD. The MOS 36-item short-form health survey (SF-36) I Conceptual framework and item selection. Med Care, 1992; 30(6): 473-83.

13. Tylka J, Piotrowicz R. Kwestionariusz oceny jakości życia SF-36 - wersja polska. Kardiol Pol, 2009; 67: 1166-69.
14. Pałczak E, Uchmanowicz I. Analiza czynników wpływających na jakość życia po zawale mięśnia sercowego. Pielęgniarstwo Zdr Publiczne, 2012; 2(1): 29-37.

15. Hinderink J, Krabbe P, Vandenbroek P. Development and application of a health-related quality-of-life instrument for adults with cochlear implants: The Nijmegen Cochlear Implant Questionnaire. Otolaryngol Head Neck Surg, 2000; 123(6): 756-65.

16. Krabbe PF, Hinderink JB, Broek P van den. The effect of cochlear implant use in postlingually deaf adults. Int J Technol Assess Health Care, 2000; 16(3): 864-73.

17. Hirschfelder A, Gräbel S, Olze H. The impact of cochlear implantation on quality of life: The role of audiologic performance and variables. Otolaryngol Head Neck Surg, 2008; 138(3): 357-62.

18. Damen GWJA, Beynon AJ, Krabbe PFM, Mulder JJS, Mylanus EAM. Cochlear implantation and quality of life in postlingually deaf adults: Long-term follow-up. Otolaryngol Head Neck Surg, 2007; 136(4): 597-604.

19. Mo B, Lindbaek M, Harris S. Cochlear implants and quality of life: a prospective study. Ear Hear, 2005; 26(2): 186-94.

20. Bess FH. The role of generic health-related quality of life measures in establishing audiological rehabilitation outcomes. Ear Hear, 2000; 21(4 Suppl): 74-79.

21. Orlewska E. Podstawy farmakoekonimiki. Jaworzno: UniMed; 1999.

22. Francis HW, Chee N, Yeagle J, Cheng A, Niparko JK. Impact of cochlear implants on the functional health status of older adults. Laryngoscope, 2002; 112(8): 1482-88.

23. Arndt S, Aschendorff A, Laszig R, Beck R, Schild C, Kroeger S i wsp. Comparison of pseudobinaural hearing to real binaural hearing rehabilitation after cochlear implantation in patients with unilateral deafness and tinnitus. Otol Neurotol, 2011; 32(1): 39-47.

24. Orabi A, Mawman D, Al-Zoubi F, Saeed S, Ramsden R. Cochlear implant outcomes and quality of life in the elderly: Manchester experience over 13 years. Clin Otolaryngol, 2006; 31(2): 116-22. 
25. UK Cochlear Implant Study Group. Criteria of candidacy for unilateral cochlear implantation in postlingually deafened adults III: Prospective evaluation of an actuarial approach to defining a criterion. Ear Hear, 2004; 25(4): 361-74.

26. Hawthorne G, Hogan A, Giles E, Stewart M, Kethel L, White $\mathrm{K}$ i wsp. Evaluating the health-related quality of life effects of cochlear implants: A prospective study of an adult cochlear implant program. Int J Audiol, 2004; 43(4): 183-92.

27. Lorens A, Obrycka A, Piotrowska A, Obszańska A. Ocena jakości życia związanej ze zdrowiem u pacjentów z zaburzeniami słuchu z wykorzystaniem kwestionariusza AQoL-D8. Now Audiofonol, 2015; 4(3 Suplement).

28. Robinson K, Gatehouse S, Browning GG. Measuring patient benefit from otorhinolaryngological surgery and therapy. Ann Otol Rhinol Laryngol, 1996; 105(6): 415-22.

29. Nikolopoulos TP, Johnson I, O'Donoghue GM. Quality of life after acoustic neuroma surgery. Laryngoscope, 1998; 108(9): 1382-85.

30. Sood S, Anthony R, Homer JJ, Van Hille P, Fenwick JD. Hypoglossal-facial nerve anastomosis: assessment of clinical results and patient benefit for facial nerve palsy following acoustic neuroma excision. Clin Otolaryngol Allied Sci, 2000; 25(3): 219-26.

31. Mckiernan D, Banfield G, Kumar R, Hinton A. Patient benefit from functional and cosmetic rhinoplasty. Clin Otolaryngol Allied Sci, 2001; 26(1): 50-52.

32. Bhattacharyya N, Tarsy D. Impact on quality of life of botulinum toxin treatments for spasmodic dysphonia and oromandibular dystonia. Arch Otolaryngol Head Neck Surg, 2001; 127(4): 389-92.

33. Vermeire K, Brokx JPL, Wuyts FL, Cochet E, Hofkens A, Van de Heyning PH. Quality-of-life benefit from cochlear implantation in the elderly. Otol Neurotol, 2005; 26(2): 188-95.

34. Newman CW, Weinstein BE, Jacobson GP, Hug GA. Test-retest reliability of the hearing handicap inventory for adults. Ear Hear, 1991; 12(5): 355-57.
35. Weinstein BE, Spitzer JB, Ventry IM. Test-retest reliability of the Hearing Handicap Inventory for the Elderly. Ear Hear, 1986; 7(5): 295-99.

36. Wexler M, Miller LW, Berliner KI, Crary WG. Psychological effects of cochlear implant: Patient and ,index relative” perceptions. Ann Otol Rhinol Laryngol Suppl, 1982; 91(2): 59-61.

37. Maillet CJ, Tyler RS, Jordan HN. Change in the quality of life of adult cochlear implant patients. Ann Otol Rhinol Laryngol Suppl, 1995; 165: 31-48.

38. Sanchez-Cuadrado I, Gavilan J, Perez-Mora R, Muñoz E, Lassaletta L. Reliability and validity of the Nijmegen Cochlear Implant Questionnaire in Spanish. Eur Arch Otorhinolaryngol, 2015; 272(7): 1621-25.

39. Liu B, Chen X-Q, Kong Y, Li Y-X, Mo L-Y, Zheng J i wsp. Quality of life after cochlear implantation in postlingually deaf adults. Zhonghua Yi Xue Za Zhi, 2008; 88(22): 1550-52.

40. Cohen SM, Labadie RF, Dietrich MS, Haynes DS. Quality of life in hearing-impaired adults: The role of cochlear implants and hearing aids. Otolaryngol Head Neck Surg, 2004; 131(4): 413-22.

41. Damen GWJA, Pennings RJE, Snik AFM, Mylanus EAM. Quality of life and cochlear implantation in Usher syndrome type I. Laryngoscope, 2006; 116(5): 723-28.

42. Klop WMC, Briaire JJ, Stiggelbout AM, Frijns JHM. Cochlear implant outcomes and quality of life in adults with prelingual deafness. Laryngoscope, 2007; 117(11): 1982-87.

43. Mistry D, Ryan J, Maessen H, Bance M. Differences in perception of hearing handicap between cochlear implant users and their spouses. Laryngoscope, 2014; 124(5): 1199-203.

44. Capretta NR, Moberly AC. Does quality of life depend on speech recognition performance for adult cochlear implant users? Laryngoscope, 2016; 126(3): 699-706.

45. Majkowicz M, Zdun-Ryżewska A. Ocena jakości życia w zaburzeniach psychicznych - koncepcja, badania, narzędzia pomiaru. Psychiatr w Prakt Klin, 2009; 2(2): 1-15. 